\author{
Vitomir Mitevski \\ Macedonian Academy of Sciences and Arts \\ Skopje \\ vitomir.mitevski@gmail.com
}

\title{
The Akritic Hero in Byzantine and Macedonian Epic Poetry
}

\begin{abstract}
Comparative analysis of the most prominent heroic characters of Byzantine (Armouris and Digenes) and Macedonian (King Marko) epic poetry uncovers numerous contact points that reveal a close relation between these two cultures over a longer period of time.

By using the term "akritic hero" or border warrior in Byzantine and the term kraishnik in Macedonian epic poetry, the paper analyses the relation between these two representations of the same type of epic hero. Complex concordance is explored on several levels which illustrate several characteristic features of the Byzantine akritic heroes Digenes and King Marko in traditional Macedonian epic poetry. Both Digenes and Marko are lone horsemen roaming in restricted territory (Cappadocia and Macedonia), they fight as individuals with distinguished opponents and even with armies, and win the fights, slay the dragon in an identical manner; there are occurrences of child-heroes in the songs and the institution of the avunculate is particularly emphasised in the act of initiation etc. Unlike the monolithic character of Homeric heroes, in Byzantine and Macedonian epic poetry both Digenes and Marko are significantly more complex and occasionally inconsistent characters, which is due to their centuries-long shaping in territories where different cultural influences are interwoven.
\end{abstract}

This is an Open Access article distributed under the terms of the Creative Commons Attribution 3.0 PL License (creativecommons.org/licenses/by/3.0/pl/), which permits redistribution, commercial and non-commercial, provided that the article is properly cited. @ The Author(s), 2018 Publisher: Institute of Slavic Studies, Polish Academy of Sciences

Editor-in-chief: Jolanta Sujecka

Conception and academic editing of this issue: Maciej Falski, Tomasz Rawski, Jolanta Sujecka with the collaboration of Ewa Niedziałek 
Keywords: Macedonian traditional epic poetry, King Marko, Byzantine epic tradition, akritic hero, Digenes Akritas, comparative analysis, horseman, child-hero, dragon slaying.

1.

\section{The Epic Hero and his World - Indo-European Hypotheses}

1 he akritic hero got his name and his special characteristics in the the Indo-European pattern developed in ancient epic poetry from India to Ancient Greece. Thus, the character of the akritic warrior, i.e. the frontiersman, can best be understood starting from the ancient epic hero as a hypothesis.

The hero in Indo-European poetry of the ancient period has several key characteristics which serve as a framework in which he moves and develops as a special type.

In line with the trifunctional structure of the hypothetic Indo-European society represented by G. Dumézil (1958), the epic hero belongs to the second class called ksatriya and rajjanya. The first noun is derived from ksatra- meaning power, while the second is derived from rāj(an)- meaning king. This clearly shows the two aspects of the Indo-European hero which define him as a warrior-king. This bond appears everywhere and at all levels in ancient Indo-European poetry, especially in the Indian epics Mahabharata and Ramayana, the Babylonian epic Gilgamesh and Homer's epics The Iliad and The Odyssey.

Royal power in the Greek world is expressed by the word кpáto contains the meaning of military capability and battle power. Thus, the stance that royal power is gained on the battlefield comes naturally. The epic hero is expected to perform a battle deed (ápı $\tau \tau \varepsilon i \alpha)$ and to obtain and secure his privileged status in the community (Riedinger, 1976).

In this context, a special epic, i.e. heroic morale is developed in the world where physical power and supremacy rule. Justice here is perceived as a right of the stronger. The hero proves himself thanks to his victory over his opponent, and in such a kratophanic world governed by natural law (just like in the animal kingdom) there is no place for condemnation of violence (Madelénat, 1986). The Homeric poet never moralises, and the biggest allowed deviation is to compare the ruthless act of the hero who kills many opponents in battle with the bloodthirsty wild beasts (lion) attacking their prey (deer, sheep etc.).

The final goal of the ancient Indo-European hero is to gain special honour among his people. Such an honour in Homer is not expressed only by acquiring a special place in the community but also by gaining material 
wealth - the victorious hero gets the largest part of the prize taken from the beaten opponent.

A special role in this poetic (imaginary) world is played by a supernatural force which ultimately governs everything. That force occurs in the individual personalisation of a god, but in Homeric poetry a special place is given to the depersonalised force of fate, i.e. $\mu$ oĩpa (West, 2007, pp. 379-385).

Within this perception, the epic hero receives a whole range of characteristics that distinguish him from the ordinary man.

Firstly, as mentioned above, the hero is of noble (royal) descent, and in some cases he has divine origin. For example, the five Pandava brothers in Mahabharata have royal status, but their mothers conceived with gods. Achilles in The Iliad is a son of the goddess Thetis etc.

Regarding appearance, the epic hero is distinguished by his beauty and incredible physical strength. In addition, he is remarkably well-built and has superhuman strength. One such typical example is Gilgamesh.

In the hero's biography, there are several places that can be noted as typical. The motif of the hero who is separated from or abandoned by his parents as an infant and left to fate until found by a saviour (a shepherd or wild animal) is known beyond the Indo-European area. From an early age, he develops rapidly and prematurely starts to walk, to run and to win games and fights with much older children. This pattern is present in Hellenic, Persian, Armenian, South-Slavonic epic poetries etc.

He performs his first heroic deeds even as an infant; for example, Heracles strangles two snakes with his bare baby-hands. Yet the most important event in this context for the hero is his initiation, i.e. proof of his maturity. It is one of the central motifs in the hero's biography. He usually proves his maturity and heroism in hunting wild beasts. Nonetheless, the most distinguished event is the abduction of his future bride. With this deed, the hero definitively proves his maturity. This deed is so widespread in the Indo-European space that abduction is almost a standard way of getting a wife.

Following inclusion in the world of the adults, the primary activity of the epic hero is his participation in fights with enemies. The opponents are different, ranging from individual warriors or rivals to whole armies, and the prevalent cases of clashes are androktasia when the hero fights with a group of opponents, or a duel when he fights with one opponent. The latter is much more common and elaborated in detail because it gives the poet a chance to develop lots of details depicting the warrior's military skills. Thus, in epic poetry duels are a typical topic consisting of a sequence of constituent parts, i.e. from the challenge and the actual fight, to the very act of killing the opponent (Fenik, 1968).

One special characteristic of the distinguished epic hero is the presence of 
his counterpart. Usually this is a companion or a close friend in the fight who, in some cases, can be a substitute for the leading hero. There are numerous examples of this: Gilgamesh and Enkidu in the Epic of Gilgamesh, Achilles and Patroclus in The Iliad or Aeneas and Pallas in Virgil's Aeneid.

Men are the main characters in heroic epic poetry, but women, although in the hero's shadow, can be very important. Unlike the woman who is the hero's mother, wife or sister and depends on him, in the Indo-European epic there are women who are independent of men. Such are the nymphs ( $v \dot{u} \mu \varphi \eta$ ) in Homer's world, apsarás in the Vedic world or vily, samovily and rusalky in Slavonic epic poetry. They are fantastic creatures that live by water, but they can confront the main hero and seduce him or even win in a fight with him (West, 2007, pp. 284-292).

Finally, it should be noted that weapons and a horse are constituent parts of the image of the epic hero. The link is so significant that the hero develops a special kind of communication with his sword and talks to it just like he talks to his horse which always has a special personal name.

2.

\section{The Byzantine Akritic Hero}

2.1. Traditional Byzantine epic poetry is known to us mainly from two texts - the Song of Armouris and the Epic of Digenes Akritas.

The Song of Armouris is preserved in two manuscripts in the Greek language, one of which was discovered in Saint Petersburg and published at the end of the 19th century, while the other was discovered and is located in Istanbul. The epic is small and consists of 200 metrically undefined verses, but it is important due to numerous archaic features regarding the style and the elaboration of motifs. The epic describes the heroism of the young Armouris who embarks on a quest to release his father who is a prisoner of the Arabs. On his journey, by the river Euphrates, he singlehandedly defeats the Arabian army and the emir agrees to free the young hero's father.

The Epic of Digenes Akritas occurs in six versions in the Greek language and four versions in archaic Slavic. Chronologically, the Slavic language versions were discovered first in Russia starting from the 19th century, and then the Greek language versions were discovered. The most important among the Slavic language versions are the Pogodin and Titov versions, while the manuscripts from the Grottaferrata monastery near Rome and Escorial near Madrid are the most prominent among the Greek language versions. It is believed that the Slavic versions are translations of the oldest original archaic Greek language versions of the epic, while the Grottaferrata version is considered to be the most artistically sleek and with most complete 
content. The Grottaferrata version is thematically divided into two parts. Out of the eight songs (books), the first three are dedicated to the emir, the father of Digenes, who abducts the daughter of the Byzantine strategist and the product of their marriage is his only son Digenes Akritas. The subsequent songs (fourth to eighth) describe the early heroics of Digenes, the abduction of the bride and his military heroics, mainly duels with the leaders of gangs, so-called Apelatai, with the Amazon female warrior Maximo, and the slaying of the dragon; the last two songs depict his peaceful life and sudden death caused by a severe disease followed by a ceremonial burial.

2.2. If we compare the characters of the two most distinguished epic heroes, Armouris and Digenes, with the abovementioned model of the Indo-European hero, we can identify many similarities.

Firstly, both of them have a noble background and higher status in the community. The father of Armouris is a Byzantine nobleman, while Digenes' background is complex - his father is an Arabian prince (emir) and his mother is a daughter of a Byzantine strategist.

With their appearance, they both correspond to the Indo-European pattern. Both are slender, handsome and physically strong, and also endlessly brave by nature.

An unusually early display of physical strength and fighting skills is a personal characteristic of both heroes. Armouris shows his strength as a 12-year-old boy when his mother gives him his father's spear and he demonstrates his physical strength and skills by folding the spear three times. The very detail of folding the father's spear three times sufficiently denotes the ritual aspect of the act of initiation through which the young hero proves his maturity as a man and the magnificence of a hero.

Digenes is almost the same young age when he goes alone to hunt wild beasts and with his bare hands overcomes a bear, a lion and a deer. Then, in the Grottaferrata version, his kinsmen approach and kiss him, while in the Slavic Titov version, after overcoming the dragon, Digenes (addressed as Devgeni in this version) washes in the sacred spring and the people around him take some water for health and strength.

The final and, one could say, mandatory act of proving maturity, is the act of abducting a bride, which is done by Digenes in all the versions. $\mathrm{He}$ abducts the daughter of the Byzantine strategist and, after several twists and turns, he overcomes the relatives of the abducted girl and after a general reconciliation they organise a wedding ceremony. Indisputably, general Indo-European patterns and motifs can be clearly identified in these acts of the Byzantine hero.

Heroic status is not something that once acquired is an everlasting 
feature of the main character. The epic hero proves his heroism throughout his life by fighting his opponents. His opponents can be distinguished representatives, such as Apelatai in the case of Digenes, but sometimes a large group of warriors and even armies that the hero, especially Armouris, overcomes and then kills them all. Of course this last motif partially deviates from the Indo-European pattern where, for example in Homer's works, the fight of the distinguished hero is usually a duel while the fight against a large number of opponents does not turn into a fictional story.

2.3. The Byzantine epic hero goes beyond the Indo-European pattern and is defined as a special type not only by the aforementioned break into the surreal, but also by several very clearly noted features.

The very name Akritas assigned to Digenes in the Greek language versions, which became part of his personal name, denotes his special role in the community. Akritas in Byzantium denoted a soldier or a protector of the borders (äkpos = border) who was assigned by the authorities to protect Byzantine citizens from neighbouring, predominantly Arab tribes. In this respect, Armouris stands out because the short epic song about him describes his fight with the Arab emir who imprisoned his father during attacks. The young hero as a true akritas goes to the eastern borders of the Empire by the river Euphrates, fights and defeats the Arabs and releases his father. Technically, Digenes is also an akritas, a border warrior, and roams in the same areas as Armouris, but unlike Armouris, Digenes never clashes with Arabs but only with individual warriors - opponents who are citizens of Byzantium. Thus, we get the image of an akritas who actually is not an akritas.

It has been said that with his appearance, physical strength and immense courage, the akritic hero corresponds with the Indo-European pattern of a hero, but in this context there is also the horse, which is an inseparable element of the image of a Byzantine warrior. It is true that Homeric heroes are also attached to their horses, which draw their battle chariots on the battlefields, but they are not horsemen. In the Byzantine world, the battle chariot has long been abandoned and the warrior fights on horseback. Therefore, we have a new image of an akritic epic hero as a horseman, which corresponds with medieval standards.

Furthermore, the ancient Indo-European hero is a leader of a great army. For example, all the famous Achaean leaders in the siege of Troy are such heroes, their large armies being described in detail in Book II of The Iliad (in the episode "The Catalogue of Ships"). On the other hand, the Byzantine akritic hero is a lone warrior. Neither Armouris nor Digenes leads an army. They regularly cross borders and go alone behind enemy lines. Armouris clashes with the great Arab army all alone, while Digenes, despite 
his accidental clash with the group of Apelatai, fights with distinguished opponents: Apelatai leaders, the Amazon Maximo or a dragon.

The moral code of the ancient hero is based on the right of the stronger. It has been mentioned that this is a kratophanic world in which the stronger has a right to overcome the weaker. It is the only way for a hero to prove himself. Olympian gods are present and take sides in a fight, but their intervention is rarely direct. The Byzantine akritic hero, on the other hand, by definition is a champion of Christianity and the only Christian God. This particularly applies to Digenes, who is profiled as a warrior for Christianity in the Grottaferrata version. Yet, in isolated cases, Digenes can go beyond the strict norms imposed on Christians and indulge in unrestricted violence and even rape. This shows the character of an akritic hero as being split into many segments, like a complex character incorporating the features of poetic metamorphosis to which he was subjected through centuries of creative processing.

\section{3.}

\section{King Marko as an Epic Hero}

3.1. The Macedonian epic cycle of King Marko

The image of King Marko in Macedonian traditional epic poetry has been distinguished and dominant since the medieval period. Marko is peerless in his importance, numerous poetic versions and popularity. Proof of this is seen in the fact that songs about King Marko from Macedonia were disseminated in neighbouring countries, predominantly in Serbia and Bulgaria, but there are also old epic songs and legends about Marko that can be found further north in the Balkans.

This research explores epic songs created in the historical ethnic Macedonia region, particularly songs in the territory of today's Republic of Macedonia. They were written down and published mostly in the 19th century, i.e. at the same time that the manuscripts of the songs of Armouris and Digenes were discovered and published. Macedonian representative songs about King Marko have been collected and republished in a compilation prepared by eminent folklore scholar Kiril Penushliski (Пенушлиски, 1983). It contains songs from the Anthology of the Miladinov brothers (reedited in 1962; Миладиновци, 1962) from Struga, songs collected by Marko Cepenkov (reedited in 1972; Цепенков, 1972) from Prilep and songs collected by Kuzman Shapkarev (reedited in 1976; Шапкарев, 1976) from Ohrid. All these songs are in the traditional Macedonian language, predominantly from the regions where the collectors lived.

A lot has been written in the literature about the origin and nature of South Slavic epic poetry, but very little has been said about the relation 
between South Slavic epic poetry, including Macedonian epic songs about King Marko as a part thereof, and the Byzantine epic tradition. Comparative systematic studies ${ }^{1}$ show that there are many contact points between these two epic traditions regarding style, motifs, typical themes, the heroic world, and especially regarding the profile of King Marko.

The Epic of Digenes was undoubtedly known a long time ago in the Slavic world, and this thesis is confirmed by the four Slavic translations discovered in the 19th and 20th centuries in Russian libraries and archives. Many language elements in those translations indicate the influence of South Slavic languages, which leaves room for the hypothesis that the translations into the Slavic languages were made in the Balkans, and then, following the Turkish conquests, in order to preserve them they were transferred north, mainly to Russia (Cf. Grégoire, 1975; Odorico, 2012; Vaillant, 1955). In Macedonia and in the southern Balkan area in general, no manuscript with a Slavic translation of the Epic of Digenes has yet been discovered, but the potential discovery of such a translation would not come as a surprise. However, the analysis of some South Slavic, and in this case Macedonian epic songs about King Marko, clearly shows that the Byzantine epic song was well known on this territory. Out of the many examples in the literature, special attention should be given to the famous song about King Marko and the daughter of the Arab emir. ${ }^{2}$ Without further elaboration on additional arguments of this type, we will conduct a comparative analysis of the character of King Marko in comparison to the distinguished Byzantine epic heroes, Armouris and Digenes Akritas.

\subsection{Indo-European features of the character of Marko}

It is obvious that the character of Marko is neither a simple nor pale reflection, nor a one-sided copy of any pattern. On the one hand, we can identify features that are typical for an akritas warrior, but on the other, we can also identify typical Indo-European features. Of course, the complex character of Marko contains special, original features which correspond to his cultural background, but this will not be discussed on this occasion.

Therefore, out of the general features, there are several most important ones that identify Marko as a typical Indo-European hero.

\footnotetext{
1 The author of this paper conducted a systematic study of this kind within the multiyear project (2013-2016) of the Macedonian Academy of Sciences and Arts titled Ancient, Byzantine and Macedonian Epic Poetry. The results obtained in the project are published in the book: Митевски, 2017.

2 In the Macedonian version, the song was published in the Anthology of the Miladinov brothers in 1861, titled Марково исповедане (Marko's confession), song 54.
} 
Fist, according to his background, Marko undoubtedly belongs to the highest echelons of the community. His noble background is denoted in his name - King Marko (Marko Krale). The typical Indo-European inversion Marko Krale (Marko the King) is dominant in the Macedonian epic tradition, while Kralot Marko (King Marko) usually denotes the historical character who is not the subject of this research.

Furthermore, according to some legends, Marko is conceived by a dragon, while according to other legends, he is nurtured by a fairy (Пенушлиски, 1983, pp. 39-40), which places him among Indo-European heroes with unusual, supernatural origins.

In his appearance, Marko does not fall behind other Indo-European epic heroes. He is an unusually well-built, strong man with an enormous moustache that frightens the enemy, and he is peerless in the courage he shows in fights. Some of the songs state that even as a child, he was easily better than his peers in various games, and he is no stranger to heroism as a young man. He proves his maturity in various, mainly conventional ways: a contest in bearing hunger or impersonating someone (a monk, Gipsy etc.) in order to surprise his opponents and kill them with his sword which only he can handle. Marko's substitutes, his nephews, are also subjected to initiation overseen by their uncle, and the very act of initiation usually comes down to hunting wild beasts or slaying a dragon. In this context, many ritual elements can be seen (stripping naked or a ritual change of clothes) which denote the archaic nature of the motif of initiation. Abducting a bride has a special place in this context as a final act for the man to be finally accepted and recognised in his community as a mature and brave man.

Similarly to ancient Indo-European epic heroes, Marko is usually involved in various duels with distinguished opponents. Those duels are usually described according to the standard Indo-European patterns which contain the elements of ritual arming before the duel, challenging the opponent, the actual fight, God's interference etc.

\subsection{Akritic parallels}

So far we have noted parallels between Marko and Byzantine epic heroes at the level of a common Indo-European base. Yet, there are many features of the character of Marko that show him to be a counterpart of Byzantine heroes - akritas.

a) It has been mentioned above that Armouris and Digenes are akritas, i.e. warriors who protect the border. Armouris proves it by fighting the Arab tribes on the eastern Byzantine border, while Digenes, despite the fact that the term akritas is part of his name, is never depicted as such in the epic 
song. Simply, he is never portrayed as a protector of the Empire's borders which he is meant to defend from foreign invaders.

Turning our attention to the character of King Marko, we note that he is also a warrior on the borders, in this case on the western border of the Turkish Empire in the Balkans, or, to be more precise, in Macedonia. Marko as an akritas warrior can be addressed as kraishnik (краишник), a term with the stem kraj (кpaj) i.e. end, border, frontier, a term that is well-known in Macedonian folklore. It is true that in some cases Marko is presented as a protector of his people from the neighbouring aggressors, but taking into consideration his main opponents, we can conclude that they are usually robbers with a vaguely defined profile. The most prominent of them is the Black Arab, who basically is a vague, mystic character. Some researchers connect this character with the chthonic deity of the Old Slavonic religion, while others try to find a historical background. Considering the possible influence of Byzantine epic poetry in which Arabs are present in various ways, it seems that this is probably a direct literary "overflow" of the character of the Arabs from the Byzantine into the Macedonian epic tradition.

Despite all this, the duels of King Marko with the Black Arab as well as with other prominent opponents (Musa Kesedžija, Bele from Kostur etc.) are usually motivated by personal reasons. Marko fights most of them in order to prove his physical and battle superiority, while he fights with Bele from Kostur in order to recover his wife who was abducted by Bele. Marko's war clashes are mostly personal battles, we can even say private wars, and have nothing to do with protecting borders. So, we arrive at the same paradox as in the case of Digenes Akritas, namely that Marko is an akritas who actually is not an akritas by his deeds. Therefore, Digenes and Marko as "akritic" heroes do not fit in the mould of general Indo-European frameworks, but establish an immediate and mutual relation.

There have been attempts to conclude that the character of Digenes is some kind of reflection of the legendary character of Alexander the Great (Veloudis, 1968). These attempts are based on some general indicators: both are great warriors, both die young of a mysterious disease etc. Here we can add the character of Marko who, according to the representative folk songs, also dies young although in an accident (from drowning). Nevertheless, despite these incidental matches, there are substantial differences. Unlike Alexander, who respects no borders in his conquests and moves across a vast territory stretching from Macedonia to India, Digenes and Marko do not go beyond the borders of their kingdoms and act in a very limited territory (the former in Cappadocia, the latter in Macedonia), which determines them as local heroes. The parallel between them is substantial, while the parallel with Alexander the Great is sporadic (Moenning, 1993). 
b) There is another comparison of Digenes Akritas and King Marko with Alexander the Great. Just like Digenes (and also Armouris), Marko is a lone warrior. They both roam on their territory as lone warriors without being accompanied by a group of warriors or an army. They always fight alone, usually with other individuals, sometimes with a group of warriors, and even with an army of opponents. As opposed to this type of lone hero, Alexander is the leader of his army, which is something completely different.

c) On the other hand, the perception of a warrior-horseman allows for a formal parallel between Alexander, Digenes and Marko, as opposed to the heroes in ancient epic songs (Indian and Hellenic), who used their horses to draw their battle chariots. The bond between the warrior-horseman and his horse is so strong that one cannot think of them otherwise than on horseback. Such is the perception of Alexander the Great in the famous mosaic in Pompeii, and such is the perception of Armouris, Digenes and Marko.

Nonetheless, the parallel between Byzantine heroes and the Macedonian epic hero contains elements (details) that make it more precise and complete. For example, when Armouris wants to find his imprisoned father, he goes to the stables and finds his father's horse completely forgotten and neglected because in the absence of his master, the horse has not drunk a drop of water for twelve years (Song of Armouris, 24). The same motif is present when Marko wants to go to Stamboul and his mare complains that it is powerless because he has forgotten and neglected it and left it without food and water for twenty years (Пенушлиски, 1983, song 80). In both cases, the first thing the heroes must do is to look after their horses.

Mounted on his horse, the hero enters into a duel with his opponent, and in some cases the close relationship between the horseman and the horse borders on identification. For example, when Digenes wants to beat the Amazon Maximo without hurting her, he kills the horse on which she is mounted. As soon as Maximo's horse is killed and she stands on foot in front of her opponent, she surrenders and accepts defeat (Grottaferrata 6. 590-592). We can note a similar situation in a duel between Sekula, Marko's nephew, and the Black Arab, when the opponents attack the horses and the death of a horse would mean defeat for one of the horsemen.

d) For the ancient as well as the Byzantine and Macedonian epic hero, the primary goal of their fight is to gain honour and glory. But closer inspection reveals a substantial difference between Homeric warriors on the one hand, and Byzantine and Macedonian warriors on the other. Namely, the leaders of the Achaean army who participate in the siege of Troy have a practical goal - to conquer and raid the city. After the city is 
conquered, each of them receives part of the plunder according to his status which is intrinsically related to personal achievements during the fight. It is formally said that everybody receives part of the plunder according to honour $\left(t_{i m} \bar{e}\right)$. Unlike Homeric heroes, Byzantine and Macedonian heroes fight for honour and glory without expecting a prize in the form of some kind of plunder. Actually, for Byzantine and Macedonian epic heroes, robbing the defeated opponent is "an act of dishonour". If we analyse the individual duels of Digenes and Marko, we note that they sometimes avoid killing the opponent and are satisfied with the very fact that the opponent admits his defeat.

To illustrate this specific manner of perceiving and experiencing heroic deeds in the epic song, we can use the scene of the Grottaferrata version in which Digenes, lying on his deathbed, speaks in detail about all his heroic deeds only for those deeds to be remembered (Grottaferrata 8. 60-120). On the other hand, it is worth noting that King Marko challenges his opponent only "to see how brave he is" (Пенушлиски, 1983, song 87), and when Marko goes to Philip the Magyar with the intention of killing him, but catches him sleeping, he wonders:

\author{
"If I kill him, \\ If I kill him now, while he sleeps, \\ What will people say about me?” (Пенушлиски, 1983, song 79).
}

e) The duel is the most popular type of epic fight. A fight between two distinguished heroes enables the poet to portray both the physical and the psychological status of the character in detail, something that is not possible in descriptions of massive fights. A duel between the best warriors of both sides is usually the climax of an epic poem and a closing act at the same time. This is the reason for the prevalence of this motif in ancient as well as Byzantine and Macedonian epic poetry, but also for a developed narrative in which numerous typical elements are used. More or less all those elements are present and used in the duels of ancient heroes, but also in the duels of Digenes and Marko.

f) Nevertheless, there is a special type of duel which is absent from Homeric epic poetry but is present in the Byzantine and Macedonian epic tradition. That duel is a fight between the main hero and a female warrior. The motif itself is not an isolated occurrence in the Indo-European epic world, but the duels of Digenes and Marko with female warriors contain some special common features. 
We have already mentioned the duel between Digenes and the Amazon Maximo (Grottaferrata, 6). Actually, he has two subsequent duels with her, and some typical elements occur. Firstly, the hero is ashamed to fight a woman because he considers it unworthy of a true man. Therefore, in both duels he does not kill her but her horse, which is enough for her to accept defeat. However, his self-restraint not to wound Maximo has another, one would say, erotic aspect. Namely, both Maximo and Digenes are dressed almost for a parade, in their most precious clothes and with specially decorated horses, which definitely depicts the motif of a ritual change of clothes. Finally, the second duel with Maximo, which is the last, ends with seduction: the hero falls into the arms of the beautiful Amazon girl and commits adultery against his wife who is waiting for him at home.

Similar elements are used in the songs about King Marko. In one of the songs (Пенушлиски, 1983, song 93), Marko is beaten by an unknown Arab and runs from the battlefield while his nephew Sekula fights and overcomes the opponent. However, before Sekula kills him with his sword, the "Arab" pulls down the upper part of his clothing and reveals that she is an Arab girl. Seduced by the girl's beauty, Sekula immediately changes his mind and decides to marry her, which is a twist of events similar to the episode of Maximo and Digenes. It is important to note that the element of disguise, i.e. changing clothes, has a key role here, too. Similarly, Marko enters into a duel with a Bagdad girl (Пенушлиски, 1983, song 100), which shows the influence of the Arab world on Macedonian epic poetry.

g) Special attention should be given to the fight of the epic hero with a dragon. This is a widespread motif in the Indo-European area, but the narratives used in the songs of Digenes and Marko reveal special features which closely link these two epic characters.

There have been long-lasting attempts in research to interpret the character of Digenes as a literary depiction of the holy warriors of Eastern Orthodoxy: St. Dimitri and St. George. ${ }^{3}$ All of them are known as warriors, and St. George is well-known from iconographic depictions as a dragon slayer.

It is true that Digenes is also depicted as a dragon slayer in both the Greek language and Slavic versions. In the Grottaferrata version, the slaying of the dragon is described as one of a sequence of the hero's valiant deeds, while in the Pogodin and Titov versions the same deed is a constituent part of the initiation of Digenes. Still, a detailed analysis of the proposed parallel between St. George and Digenes as dragon slayers reveals several key differences. In short, the saint in the representative icons is depicted as a horse-mounted

Trapp was the first to note this, and lately Elizbarashvili, 2010. 
hero stabbing the dragon (a type of one-headed reptile) on the ground with his spear. On the other hand, Digenes in all the versions (Greek language and Slavic) slays the dragon while standing on his feet (the horse is absent), by cutting off its three (four in the Pogodin version) heads with his sword. All of this shows that the two depictions are completely different, so it is difficult to talk about similarities or any specific influence.

In representative Macedonian songs about King Marko published in the collection of K. Penushliski, the slaying of the dragon is described in two cases (Пенушлиски, 1983, songs 1 and 11). There are also attempts here to draw a parallel between Marko and St. George who kills the dragon, but a detailed analysis again reveals some fundamental differences between the elements of the description. Actually, Marko, just like Digenes, slays the dragon by cutting off its three heads with his sword, without being mounted on a horse. ${ }^{4}$

All of these facts show that the motif of dragon slaying by Digenes Akritas and King Marko is not in close relation with the dragon slaying by St. George, but at the same time they show that the dragon slaying by the Byzantine epic hero matches the dragon slaying by the Macedonian epic hero down to the smallest details, which can mean that the development of the motif comes from another common source.

h) In several songs about Marko, some of his little nephews appear as dragon slayers, thus developing the motif of the child hero in the role of a substitute for the main character (Пенушлиски, 1983, songs 85 and 90).

In Byzantine epic poetry there are traces of the Indo-European motif of the child hero. Actually, Armouris and Digenes appear as child heroes. Armouris performs his heroic deed destroying an army of Arabs when he is 12 years old, while Digenes in all the versions is depicted as a 12- or 13-yearold hero who hunts and kills wild beasts. Marko, too, is depicted as a hero when he was a child, but it is very interesting to note that in the Macedonian cycle of songs about King Marko, there are other child heroes as well. These characters have various names: child Tatomirche, child Dukadinche, child Golomeshe, child Malianche, child Sekula etc. To some extent, there are similar characters in other South Slavic epic songs, but, as explained by a specialist (Medenica, 1977, pp. 281-282), they are typical for Macedonian traditional epic poetry. Some of them are Marko's opponents, but most of them are his nephews from his sister. The latter usually have the role of Marko's substitute and they replace their uncle in fights with opponents.

This is described in detail by Penushliski (Пенушлиски, 1983), song 1. 
Substitution is a well-known Indo-European idea, but it acquires special characteristics in the Epic of Digenes and in the cycle of songs about King Marko. The relation between the main hero and his deputy is defined as the relation between uncle and nephew, known as the avunculate. Deeply rooted in the matriarchal past, the bond between uncle and nephew is so strong that it frequently substitutes for the bond between father and son. In the Epic of Digenes, traces of that relation can be recognised in the act of initiation. In almost all the versions, and most strikingly in the Grottaferrata version (4. 70-220), during the first initiation of Digenes who goes hunting wild beasts, his father is mentioned only in the beginning of the episode, trying to dissuade his son from what is a risky act for such a young man. But after Digenes attacks the bears, the lion and the other animals, the father simply disappears from the scene and is replaced by uncle Constantine. He is present and directly gives advice to his initiant nephew on how to overcome the beasts with his bare hands in order to gain fame and to be accepted as a hero. After proving himself as a hunter, Digenes does not speak to his father but to his uncle, asking him to be a witness of his first heroic deed with the words:

You see, my golden lord, God's mighty work! (Grottaferrata, 4. 188; transl. E. Jeffreys; Jeffreys, 1998).

In the cycle of songs about King Marko, the nephews are usually child Malianche, child Tatomirche and child Sekula, and their uncle Marko has a special role in their initiation. For example, in one song Marko tests the courage and maturity of his nephew child Tatomirche disguised as a naked dervish (гола дервииина), i.e. dressed in ritual clothes: he attacks and scares his nephew, only to finally reveal himself to the petrified boy, admitting he only wanted to see "how brave his heart is" (Пенушлиски, 1983, song 86).

The role of Marko as an uncle also appears in other forms of initiation: when he introduces his nephew into the fellowship of men at various gatherings or marriage parties, and other times when the nephew has to prove his courage and maturity by overcoming various challenges in order to marry the emperor's daughter. In both cases, Marko's task is to advise his nephew how to overcome the dangers, and on several occasions he even lends him his horse and his weapons with instructions how to use them best.

These examples sufficiently illustrate the close link between the form of the avunculate in the Epic of Digenes and in Macedonian songs about King Marko.

i) There is one additional feature that is common for the characters of Digenes and Marko, and that feature is their Christianity. The presence of 
the divine world and the intermittent interference of the gods are a common occurrence in Indo-European ancient poetry from India to Ancient Greece, but the heroes very often step out as individual characters and in some cases in The Iliad it is possible for the hero to oppose a god. One such example is Diomedes, who attacks and wounds Ares, the god of war, at the end of Book V.

On the other hand, the Byzantine epic hero steps out as a champion of Christianity. As a matter of fact, at the beginning of the Grottaferrata version, Digenes is celebrated as a big champion of Christianity. Despite the fact that this version of the epic song is a product of subsequent interventions, thus the presence of Christian ideology is even more emphasized, the impression remains that Digenes in all the Greek language versions, and even in the archaic Slavic versions, is depicted as a hero-champion of Christianity. Therefore, his acts are no longer a result only of personal beliefs like the acts of ancient heroes, but are usually interpreted as a representation of God's justice and protection of the weak and oppressed. The hero himself regularly puts himself in the service of God's will.

Turning our attention to the character of King Marko, we discover that he also follows the same idea. He often explains and justifies his acts as a defence of Christian justice, and manifests his deep piety in various ways: he observes Great Lent, attends the liturgy on Mount Athos, builds monasteries etc. Of course, this portrayal is not unusual considering the fact that the epic character of King Marko is a product of Macedonian Christians.

j) Nevertheless, in a wider perspective the comparison between the characters of Digenes and Marko demonstrates another common feature which, considering their general profile, can be said to lack consistency.

As an example we can use the abovementioned episode of the Grottaferrata version (Book V) in which, in a desert oasis, Digenes meets a lone girl who tells him that she was abandoned by her unfaithful lover. Digenes promises to help her, puts her on his horse, but is overwhelmed by love and lust and rapes her. By doing so, he not only commits adultery against his wife, but turns himself into an abuser. Subsequent attempts by devoted editors to alleviate the consequences of the great hero's immoral and sacrilegious act through minor interventions in the text are futile.

The Macedonian song Marko's Confession (Марково исповедағе; Miladinov brothers, song 54) presents the same story: Marko rapes "the Arab girl" and after the act bitterly repents for abusing the helpless girl and for the sin committed before God.

Some interpreters' attempts to somehow justify Marko are as futile and naïve as in Digenes' case. We should look for the only explanation for heroes' 
deviation from the principles of God's justice not in moralisations but in the complex genesis of these multifaceted epic characters. By comparison, Homeric characters in general give a monolithic impression, which can be seen in epithets that are used consistently. For example, Odysseus is cunning and much-enduring, Agamemnon is a shepherd of the people etc. On the other hand, Penelope is a typical example of a faithful wife who is never tempted to commit adultery against her husband. Unlike these characters, Digenes and Marko are characters who have been built and formed over a long period of time and in cultural environments (Byzantium and Macedonia) which were always exposed to foreign influences. Those influences and constant changes in beliefs and customs throughout the centuries contributed to the complex composition of the characters of these epic heroes. In today's world, these characters have been shaped as a notional amalgam containing sediments (strata) from various periods of time and different cultures.

That is why we could say that Digenes Akritas and King Marko are epic heroes with many faces. This distinguishes them from the others and brings them close to each other as typical heroes, i.e. products of similar cultural movements and changes.

\section{References}

Beaton, R., \& Ricks, D. (Eds.). (1993). Digenes Akrites: New approaches to Byzantine heroic poetry. Aldershot: Routledge.

Beck, H. G. (1971). Geschichte der byzantinischen Volksliteratur. München: Beck. (Handbuch der Altertumswissenschaft).

Burkert, W. (1985). Greek religion. Cambridge, MA: Blackwell.

Danka, I. R. (1998). De Babylonia Gilgamide cum carminibus Homeri comparat. Łódź: Wyd. UŁ.

Dumézil, G. (1958). L’idéologie tripartite des Indo-Européens. Bruxelles: Latomus.

Elizbarashvili, E. (2010). The formation of a hero in Digenes Akrites. Greek, Roman, and Byzantine Studies, 50(3), 437-460.

Fenik, B. (1968). Typical battle scenes in the Iliad: Studies in the narrative techniques of homeric battle description. Wiesbaden: Steiner.

Grégoire, H. (1975). Autour de l'épopée byzantine. London: Variorum Reprints.

Jeffreys, E. (Ed.). (1998). Digenis Akritis: The Grottaferrata and Escorial versions. Cambridge: Cambridge University Press.

Lord, A. B. (1960). The singer of tales. Cambridge, MA: Harvard University Press.

Madelénat, D. (1986). L'épopée. Paris: PUF.

Mavrogordato, J. (Ed.). (1956). Digenis Akrites: Edited with an introduction, translation and commentary. Oxford: Clarendon Press. 
Medenica, R. (1977). Značaj arhaičnih elemenata u narodnoj epici Makedonije. In Зборник од ХІХ Конгрес на Сојузот на здруженијата на фолклористите на Југоставија - Крушево 1972 (рр. 279-283). Скопје.

Mitevski, V. (2016). Three epic motifs from Homeric, Byzantine, and Macedonian epic poetry. Živa antika, 66(1-2), 25-35.

Moenning, U. (1993). Digenes=Alexander? The relationship between Digenes Akrites and the Byzantine Alexander Romance in their different versions. In R. Beaton \& D. Ricks (Eds.), Digenes Akrites: New approaches to Byzantine heroic poetry (pp. 103-115). Aldershot: Routledge.

Odorico, P. de. (2012). L’Akrite: L'épopée byzantine de Digénis Akritas. Toulouse: Anacharsis.

Powell, B. B. (2004). Homer. Oxford: Oxford University Press.

Riedinger, J.-C. (1976). Remarques sur la TIMH chez Homère. Revue des Études Grecques, 89(426-427), 244-264. https://doi.org/10.3406/reg.1976.4107

Trapp, E. (Ed.). (1971). Digenes Akrites: Synoptische Ausgabe der ältesten Versionen. Wien: Böhlau. (Wiener Byzantinistische Studien, 8).

Vaillant, A. (1955). Le Digénis slave. Прилози за кюижевност, језик, историју и фолклор, 21(3-4), 197-228.

Veloudis, G. (1968). Der neuegriechische Alexander: Tradition in Bewahrung und Wandel. München: Univ. München.

West, M. L. (2007). Indo-European poetry and myth. Oxford: Oxford University Press. https://doi.org/10.1093/acprof:oso/9780199280759.001.0001

Кузьмина, В. Д. (1953). Новый список “Девгениева деяния”. Труды Отдела древнерусской литературы Института русской титературы, 1953(9), 339-360.

Кузьмина, В. Д. (1962). Девгениево деяние (Деяние прежних времен храбрых человек). Москва: Изд. АН СССР.

Миладиновци. (1962). Зборник 1861-1961. Скопје: Кочо Рацин.

Митевски, В. (2001). Хеленска епика: Хелада и Рим. Скопје: Матица македонска.

Митевски, В. (2017). Сенката на Марко Крале: Античката, византиската и македонската епска поезија [The shadow of King Marko: Ancient, Byzantine and Macedonian epic poetry]. Скопје: МАНУ.

Пенушлиски, К. (1983). Марко Крале: Легенда и стварност. Скопје:Мисла. .

Сыркин, А. Я. (Ed.). (1960). Дигенис Акрит: Перевод, статьи и комментарии. Москва: Издателъство Академии наук СССР.

Творогов, О. В. (Ed., Trans. \& Comm.). (1981). Девгениево деяние. In Памятники литературь Древней Руси: ХІІІ век (рp. 28-65, 531-533). Москва: Издательство "Художественная литература".

Фрейберг, Л. А., \& Попова, Т. В. (1978). Византийская литература эпохи расивета $I X-X V$ вв. Москва: "Наука”.

Цепенков, М. К. (1972). Македонски народни умотворби: Кн. 1. Народни песни. Скопје: Македонска книга.

Шапкарев, К. А. (1976). Избрани дела (Vol. 2) (ed. by Т. Саздов). Скопје: Мисла. 


\section{References (Transliteration)}

Beaton, R., \& Ricks, D. (Eds.). (1993). Digenes Akrites: New approaches to Byzantine heroic poetry. Aldershot: Routledge.

Beck, H. G. (1971). Geschichte der byzantinischen Volksliteratur. München: Beck. (Handbuch der Altertumswissenschaft).

Burkert, W. (1985). Greek religion. Cambridge, MA: Blackwell.

Cepenkov, M. K. (1972). Makedonski narodni umotvorbi: Kn. 1. Narodni pesni. Skopje: Македонска книга.

Danka, I. R. (1998). De Babylonia Gilgamide cum carminibus Homeri comparat. Łódź: Wyd. UŁ.

Dumézil, G. (1958). L’idéologie tripartite des Indo-Européens. Bruxelles: Latomus.

Elizbarashvili, E. (2010). The formation of a hero in Digenes Akrites. Greek, Roman, and Byzantine Studies, 2010(50), 437-460.

Fenik, B. (1968). Typical battle scenes in the Iliad: Studies in the narrative techniques of homeric battle description. Wiesbaden: Steiner.

Freĭberg, L. A., \& Popova, T. V. (1978). Vizantiǔskaia literatura épokhi rastsveta IX-XV vv. Moskva: "Nauka".

Grégoire, H. (1975). Autour de l'épopée byzantine. London: Variorum Reprints.

Jeffreys, E. (Ed.). (1998). Digenis Akritis: The Grottaferrata and Escorial versions. Cambridge: Cambridge University Press.

Kuz'mina, V.D. (1953). Novyı̌ spisok “Devgenieva deianiia”. Trudy Otdela drevnerusskoŭ literatury Instituta russkoĭ literatury, 1953(9), 339-360.

Kuz'mina, V. D. (1962). Devgenievo deianie (Deianie prezhnikh vremen khrabrykh chelovek). Moskva: Izd. AN SSSR.

Lord, A. B. (1960). The singer of tales. Cambridge, MA: Harvard University Press.

Madelénat, D. (1986). L'épopée. Paris: PUF.

Mavrogordato, J. (Ed.). (1956). Digenis Akrites: Edited with an introduction, translation and commentary. Oxford: Clarendon Press.

Medenica, R. (1977). Značaj arhaičnih elemenata u narodnoj epici Makedonije. In Zbornik od XIX Kongres na Sojuzot na združenijata na folkloristite na Jugoslavija - Kruševo 1972 (pp. 279-283). Skopje.

Miladinovci. (1962). Zbornik 1861-1961. Skopje: Kočo Racin.

Mitevski, V. (2001). Helenska epika: Helada i Rim. Skopje: Matica makedonska.

Mitevski, V. (2016). Three epic motifs from Homeric, Byzantine, and Macedonian epic poetry. Živa antika, 66(1-2), 25-35.

Mitevski, V. (2017). Senkata na Marko Krale: Antičkata, vizantiskata i makedonskata epska poezija [The shadow of King Marko: Ancient, Byzantine and Macedonian epic poetry]. Skopje: MANU.

Moenning, U. (1993). Digenes=Alexander? The relationship between Digenes Akrites and the Byzantine Alexander Romance in their different versions. In R. Beaton 
\& D. Ricks (Eds.), Digenes Akrites: New approaches to Byzantine heroic poetry (pp. 103-115). Aldershot: Routledge.

Odorico, P. de. (2012). L’Akrite: L’épopée byzantine de Digénis Akritas. Toulouse: Anacharsis.

Penušlinski, K. (1983). Marko Krale: Legenda i stvarnost. Skopje: Misla.

Powell, B. B. (2004). Homer. Oxford: Oxford University Press.

Riedinger, J.-C. (1976). Remarques sur la TIMH chez Homère. Revue des Études Grecques, 89(426-427), 244-264. https://doi.org/10.3406/reg.1976.4107

Šapkarev K. A. (1976). Izbrani dela (Vol. 2) (ed. by T. Sazdov). Skopje: Misla.

Syrkin, A. I. (Ed.). (1960). Digenis Akrit: Perevod, stat'i i kommentarii. Moskva: Izdatel'stvo Akademii nauk SSSR.

Trapp, E. (Ed.). (1971). Digenes Akrites: Synoptische Ausgabe der ältesten Versionen. Wien: Böhlau. (Wiener Byzantinistische Studien, 8).

Tvorogov, O. V. (Ed., Trans. \& Comm.). (1981). Devgenievo deianie. In Pamiatniki literatury Drevně Rusi: XIII vek (pp. 28-65, 531-533). Moskva: Izdatel'stvo "Khudozhestvennaia literatura".

Vaillant, A. (1955). Le Digénis slave. Prilozi za književnost, jezik, istoriju i folklor, 21(3-4), 197-228.

Veloudis, G. (1968). Der neuegriechische Alexander: Tradition in Bewahrung und Wandel. München: Univ. München.

West, M. L. (2007). Indo-European poetry and myth. Oxford: Oxford University Press. https://doi.org/10.1093/acprof:oso/9780199280759.001.0001

\section{Акритскиот херој во византиската \\ и македонскатаепска поезија}

Споредбената анализа на најистакнатите херојски ликови на византиската (Армурис и Дигенис) и македонската (Марко Крале) епика открива низа допирни точки што сведочи за блискиот контакт меѓу овие две култури во тек на подолг временски период.

На примерот на поимот за т. н. акритски херој т. е. воин од граничните предели кој во македонската епика го носи називот краишник со идентично значење, во текстот се истражува меѓусебниот однос на овие две пројави на еден ист тип епски херој. Комплексното соодветство се развива на повеќе нивоа при што краишникот Марко Крале во македонската традиционална епска поезија се истакнуива со низа типични „акритски“ обележја. Така, и Дигенис и Марко се осамени коњаници кои се движат на ограничен простор (Кападокија односно Македонија), стапуваат како единка во двобои со истакнати 
противници, па дури и со цели војски и од нив излегуваат како победници, на идентичен начин го погубуваат змејот, во песните за нив се јавуваат деца-јунаци при што и на двете страни акцент се става на институтцијата на авункулат што особено важи во чинот на иницијација итн.

Наспроти монолитниот карактер на хомерските херои, во византискиот и македонскиот еп Дигенис и Марко се многу покомплексни и понекогаш противречни фигури што е резултат на нивното повеќевековно поетско обликување на простори каде што се преплетуваат најразлични влијанија.

Клучни зборови: Македонска традиционална епика, Марко Крале, византиска епска традиција, акритски херој (краишник), Дигенис Акрит, споредбена анализа, коњаник, дете-јунак, погубување на змејот.

\section{Bohater z pogranicza w bizantyjskiej i macedońskiej poezji epickiej}

Analiza komparatystyczna najbardziej wyrazistych postaci w bizantyjskiej (Armuris i Digenis) i macedońskiej (Królewicz Marko) epice ujawnia szereg punktów wspólnych, co świadczy o bliskich kontaktach pomiędzy tymi dwiema kulturami w długim okresie czasu.

$\mathrm{Na}$ przykładzie pojęcia akryty, to znaczy żołnierza z pogranicza [Cesarstwa Wschodniorzymskiego], który w macedońskiej epice jest nazywany pogranicznikiem i jest nośnikiem takiego samego znaczenia (jak termin akryta), w artykule analizowany jest wzajemny stosunek tych dwóch odmian tego samego typu bohatera epickiego. Kompleksowa analiza uwidacznia podobieństwo na wielu poziomach, przy czym akryta - pogranicznik Królewicz Marko w macedońskiej tradycyjnej poezji epickiej odznacza się szeregiem charakterystycznych cech właściwych akrycie. Tak oto, i Digenis, i Karólewicz Marko są samotnymi wojownikami, którzy poruszają się po ograniczonej przestrzeni (Kapadocja i Macedonia), stają samotnie do dwuboju z wybitnymi przeciwnikami, a nawet z całymi armiami i wychodzą z nich zwycięsko, w ten sam sposób pokonują żmija, w pieśniach o nich występują dzieci-junacy, przy czym w obydwu kontekstach (bizantyjskim i macedońskim) jest kładziony akcent na instytucję awunkulatu (avunculus), co ma szczególne znaczenie w kontekście aktu inicjacji, itd. W przeciwieństwie do monolitycznego charakteru bohaterów homeryckich, w bizantyjskim 
i macedońskim eposie, Digenis i Królewicz Marko są postaciami o wiele bardziej kompleksowymi i wewnętrznie sprzecznymi, co wynika $z$ ich wielowiekowego poetyckiego kształtowania się na terenach, na których krzyżują się najróżnorodniejsze wpływy.

Słowa kluczowe: Macedońska tradycyjna poezja epicka, Królewicz Marko, bizantyjska tradycja epicka, akryta (bohater z pogranicza), Digenis akryta, analiza komparatystyczna, jeździec, bohater-dziecko, zabicie żmija.

Przekład z języka macedońskiego Jolanta Sujecka

\section{Note}

Vitomir Mitevski [Витомир Митевски], Macedonian Academy of Sciences and Arts, Skopje.

vitomir.mitevski@gmail.com

The preparation of the article was self-funded by the author.

No competing interests have been declared. 